\title{
Notes
}

\section{The Applicability of Just Compensation to Substantive Due Process Claims}

\author{
Stuart Minor Benjamin
}

In Arroyo Vista Partners v. County of Santa Barbara, ${ }^{1}$ a real estate development company brought suit against local zoning authorities claiming that those authorities denied the company its constitutional rights to property. Interestingly, the developer did not bring a claim under the clause that property owners usually invoke, namely, the takings clause of the Fifth Amendment of the U.S. Constitution; ${ }^{2}$ rather, the developer "carefully avoided alleging a federal taking claim"3 and instead brought a substantive due process claim under the due process clause of the Fourteenth Amendment. ${ }^{4}$ The refusal to allege a federal taking may seem surprising, but the litigation strategy actually represents a straightforward response to the ripeness requirements imposed on takings claims, but not explicitly required of substantive due process claims, in Williamson County Regional Planning Commission v. Hamilton Bank. ${ }^{5}$

In Williamson County, the U.S. Supreme Court ruled that property owners do not have justiciable takings claims until they are denied just compensation in state proceedings. As a result of Williamson County, property owners who

1. 732 F. Supp. 1046 (C.D. Cal. 1990).

2. "[P]rivate property [shall not] be taken for public use, without just compensation." U.S. CONST. amend. V.

3. 732 F. Supp. at 1050 .

4. "No state shall ... deprive any person of life, liberty, or property, without due process of law ...." U.S. CONST. amend. XIV, § 1.

5. 473 U.S. 172 (1985). 
otherwise would have federal takings claims must perfect their claims-by pursuing them in state proceedings-before they can enter federal court. The Williamson County Court did not address the effect of its ruling upon substantive due process claims that are based on the same facts as takings claims, as no substantive due process claim was before the Court. ${ }^{6}$ In many propertybased constitutional cases, however, property ${ }^{7}$ owners claim that a given state or local agency act violates both the takings clause of the Fifth Amendment and the substantive component of the due process clause of the Fourteenth Amendment $^{8}$ (or, as in Arroyo, they allege a substantive due process claim and forego the takings claim). ${ }^{9}$ In the absence of a definitive ruling from the Supreme Court, the lower courts have split as to whether the requirement of pursuit of just compensation at the state level applies to substantive due process claims. This Note addresses that split and possible solutions to the problems it presents.

The specific question at hand-whether federal courts can properly dismiss substantive due process cases because of failure to pursue just compensationshould not obscure the larger issue of access to federal courts; the inquiry that underlies this Note is whether there are constitutional or prudential reasons that justify the federal courts' broadening of ripeness requirements for propertybased substantive due process claims to the extent that plaintiffs are forced to utilize state proceedings before they are allowed to enter federal court.

Part I of the Note outlines the property-based constitutional claims that a property owner can bring. Part II delineates the requirement, propounded in Williamson County, that plaintiffs pursue just compensation in a state forum. Part III discusses the First and Ninth Circuits' application of Williamson County to substantive due process claims. Part IV outlines the shortcomings of sending a substantive due process claim to state proceedings. Part V discusses the disadvantages of failing to send a substantive due process claim to state pro-

6. The property owner had brought a substantive due process claim at the trial level but did not raise the issue in the Supreme Court.

7. Though any kind of property can be the basis of a takings or substantive due process claim, the overwhelming majority involve real property. For this reason, this Note uses the terms "land" and "property" interchangeably. Most of the analysis in this Note applies to any takings or substantive due process claim, however, whether the property involved is real or personal.

8. It may seem surprising that the Supreme Court has permitted the use of substantive due process for this purpose, given the widespread repudiation of the Lochner era cases. In fact, in both Moore v. City of East Cleveland, 431 U.S. 494 (1977), and Village of Belle Terre v. Boraas, 416 U.S. 1 (1974), the Supreme Court not only explicitly accepted the use of substantive due process in the property context but also applied a substantive due process test to property-based claims; in these cases, the Court utilized the test outlined in Nectow v. City of Cambridge, 277 U.S. 183 (1928), and Village of Euclid v. Ambler Realty Co., 272 U.S. 365 (1926); see also San Diego Gas \& Elec. v. City of San Diego, 450 U.S. 621, 656 n.23 (1981) (Brennan, J., dissenting) (if regulation does not further public health, safety or morals, landowner may sue for Fourteenth Amendment due process violation).

9. In fact, in all but two of the cases mentioned in this Note, the plaintiff brought a substantive due process claim in conjunction with a takings claim. The two exceptions, Arroyo and Greenbriar, Ltd. v. City of Alabaster, $881 \mathrm{~F} .2 \mathrm{~d} 1570$ (11 th Cir. 1989), involved plaintiffs who refrained from including takings claims to avoid the ripeness requirements of Williamson County. Telephone interview with Kenneth Bley, Counsel to Arroyo Vista Partners (Feb. 25, 1991); telephone interview with F.A. Flowers III, Counsel to Greenbriar, Ltd. (Feb. 21, 1991). 
ceedings. Finally, Part VI argues that the best solution lies in abandoning the Williamson County just compensation requirement entirely.

\section{Takings and Substantive Due Process Claims}

When a government officially condemns or expropriates a parcel of land, it is asserting its power of eminent domain. On some occasions, however, a governmental entity regulates the use of property in such a way that, despite its failure to initiate formal eminent domain proceedings, its action amounts to an appropriation of the land. ${ }^{10}$ In such situations, the property owner may bring suit against the government under the takings clause with a claim known as inverse condemnation. The term "inverse" is used because the property owner, not the government, initiates the proceedings. The basis of an inverse condemnation claim is that the government, by virtue of its regulation, has impaired the property to such an extent that it has deprived the owner of the use of the property and has thereby effected a de facto appropriation. The property owner claims that, since the government has taken his land, the court should either prevent the government from continuing the taking or force the government to give him just compensation for it. ${ }^{11}$

In addition to an inverse condemnation claim, a landowner can bring a second type of property-based constitutional claim to challenge the substance ${ }^{12}$ of a state or local governmental ${ }^{13}$ action: the property owner can claim that a given governmental action is so arbitrary or unfair that it constitutes a violation of the substantive component of the due process clause of the Fourteenth Amendment. ${ }^{14}$ Such a substantive due process claim can be brought independently of any Fifth Amendment claim; the preponderance of cases involving substantive due process claims, however, also involve takings claims. ${ }^{15}$

10. Challenges to regulations, as opposed to challenges to acts that physically take property, are known as claims of a regulatory taking. It is these takings claims that have been used most commonly and are the focus of the most heated debate.

11. See Comment, Civil Rights for the Propertied Class: The Development of Inverse Condemnation in the Federal Courts, 55 TUL. L. REv. 897 (1981).

12. A property owner could also challenge the government's procedure for its action (e.g., by alleging that the government failed to provide notice or adequate procedures through which she could contest a governmental action) rather than the substance of an act. In such a case, the property owner would claim that she was deprived of the procedural due process guaranteed to her by the Fourteenth Amendment. This Note will not examine such claims, however, but instead will focus on the ripeness threshold for substantive due process claims.

13. When a property owner challenges an action by the federal government, rather than a state or local government, he does not invoke the Fourteenth Amendment (which, by its terms, applies only to the states), but instead directly relies on the takings and due process clauses of the Fifth Amendment and sues in the U.S. Claims Court.

14. Both of these claims are generally brought under 42 U.S.C. $\$ 1983$ (1988). Section 1983 gives an individual a cause of action against anyone who, under color of state law, deprives that individual "of any rights, privileges, or immunities secured by the Constitution and laws."

15. See supra note 9. 
Substantive due process and takings claims arise from different clauses of the Constitution and thus have different legal foundations. As noted above, the basis of an inverse condemnation claim is that the government deprived a property owner of her right to control a given parcel of land and did not pay for that deprivation. A substantive due process claim, on the other hand, is based on a government's failure to treat its citizens with some minimum standard of rationality and fairness called "due process."16 The standard for takings is thus result-based, focusing on the effect of a given regulation upon a given piece of land. The standard for substantive due process, on the other hand, is more goal-based, ${ }^{17}$ concentrating on whether the government's aims are "clearly arbitrary and unreasonable, having no substantial relation to the public health, safety, morals, or general welfare."18

The differences in the nature of the claims are reflected in conceptually dissimilar remedies. An inverse condemnation action attempts to force the government either to stop appropriating the land or to acknowledge its appropriation and compensate for the rights it has taken. A substantive due process claim, on the other hand, seeks damages from the government for its failure to treat the property owner fairly, or, in the alternative, attempts to enjoin the government from continuing its unfair action.

Despite the theoretical differences between damages and compensation, however, the remedies have the same practical result: both seek an end to the challenged government action or monetary relief. Furthermore, though a damages award can differ in amount from just compensation, it is not clear that there will be any significant disparity in actuality: ${ }^{19}$ the same rules for punitive damages and attorneys' fees apply to both takings and substantive due process

16. Some commentators have suggested that, in determining whether a taking has occurred, the courts should apply a due process test based on an "unfair and arbitrary" standard. See, e.g., Kelso, Substantive Due Process as a Limit on Police Power Regulatory Takings, 20 WILLAMETTE L. REV. 1, 14-26 (1984); Strong, On Placing Property Due Process Center Stage in Takings Jurisprudence, 49 OHIO ST. L.J. 593, 615-22 (1988). Though the Supreme Court has considered explicitly adopting a due process test for takings claims, it has never done so. In fact, the Court in Williamson County noted the argument for applying a due process standard to takings claims, but did not reach this issue because it ruled that the claim was unripe. 473 U.S. at 197-200.

17. This differentiation between takings and substantive due process can also be seen as a result/process distinction. See Carlisle, The Section 1983 Land Use Case: Justice Stevens and the Hunt for the Taking Quark, 16 STETSON L. REV. 565 (1987).

18. Village of Euclid v. Ambler Rezlty Co., 272 U.S. 365, 395 (1926). This same standard was applied in two recent cases, where it was quoted verbatim: Greenbriar, Ltd. v. City of Alabaster, 881 F.2d 1570, 1577 (11th Cir. 1989), and Sinaloa Lake Owners Ass'n v. City of Simi Valley, 882 F.2d 1398, 1407 (9th Cir. 1989), cert. denied sub nom. Doody v. Sinaloa Lake Owner's Ass'n, 110 S. Ct. 1317 (1990); see also Burrell v. City of Kankakee, 815 F.2d 1127, 1129 (7th Cir. 1987); Moore v. City of East Cleveland, 431 U.S. 494, 498 n.6 (1977) (plurality opinion); id. at 514 (Stevens, J., concurring).

19. See, e.g., Wheeler v. City of Pleasant Grove, 833 F.2d 267, 270 n.3 (11th Cir. 1987) (for Fifth Amendment takings and Fourteenth Amendment substantive due process claims, "the measure of damages to which the aggrieved landowner is entitled is the same"). 
claims ${ }^{20}$ and compensatory awards for both claims will be based on the degree of impairment and consequential loss in value of the property. ${ }^{21}$

Takings and substantive due process claims also usually have the same factual bases: many plaintiffs allege that a given government action constitutes both a taking and a deprivation of due process. In fact, in all of the cases cited in this Note, the factual bases of the claims were identical. ${ }^{22}$

Takings and substantive due process claims, then, have different legal foundations which lead to different tests and conceptually distinct monetary awards; the two claims, however, usually arise from the same event and may yield the same monetary award. The doctrinal differences between the claims, combined with the practical similarities, have made it difficult for courts to determine whether the claims should be subject to the same ripeness thresholds.

\section{The Williamson County Case}

The plaintiff in Williamson County was a property owner who sued the county planning commission under section 1983 on a takings claim predicated on the commission's refusal to approve the owner's development plans. The Supreme Court held that the property owner's claim was unripe for two reasons, either of which was sufficient to dismiss the case: first, the property owner "ha[d] not yet obtained a final decision regarding how it [would] be allowed to develop its property,"23 and second, the property owner "did not seek compensation through the procedures the State ha[d] provided for doing so."24

20. The Supreme Court has ruled that municipalities are immune from punitive damages under section 1983, irrespective of the claim. City of Newport v. Fact Concerts, Inc., 453 U.S. 247, 268 (1981). In addition, the Court has ruled that 42 U.S.C. $\$ 1988$, which provides for attorneys' fees, applies to all claims brought under section 1983. Maine v. Thiboutot, 448 U.S. 1, 9-11 (1980).

21. See Nahmod, The Section 1983 Damage Action: An Overview, 60 CHI.-KENT L. REv. 39 (1984); Rockwell, Constitutional Violations in Zoning: The Emerging Section 1983 Damage Remedy, 33 U. FLA. L. REV. 168 (1981). On the level of damages and the uncertainty surrounding them, see generally $1 \mathrm{I}$. BODENSTEINER \& R. LEVINSON, STATE AND LOCAL GOVERNMENT CIVIL RIGHTS LIABILITY \$\$ 1.42-.55 (1987 \& Supp. 1990); Friedman, Constitutional Torts, in SEction 1983 CrVIL RIGHTS LITIGATION AND ATTORNEY' FEES 1989, at 233, 418-24 (PLI Litig. \& Admin. Practice Course Handbook Series No. 380, 1989). The Supreme Court noted the lack of consensus on the level of damages in City of Newport, 453 U.S. at 256 ("[The] contours [of municipal liability under 42 U.S.C. $\$ 1983$ ] are currently in a state of evolving definition and uncertainty.").

22. For example, in Simi Valley, when a state agency breached a dam and thereby damaged the lake behind the dam, the owners of the dam and the lake claimed both that the agency's action "took" their land by impairing their property and that it acted unreasonably and arbitrarily because it deprived them of their property rights. See 882 F.2d at 1401. The court in Simi Valley acknowledged the similarities of the claims but did not find it dispositive: "It is of no moment that this due process claim is based on factors that also form the basis of an alleged taking. Two or more legal theories may cover the same conduct and a plaintiff is entitled to prove each claim according to its terms." Id. at 1404.

23. 473 U.S. at 190.

24. Id. at 194. The Court ruled that a property owner can avoid this second requirement only if the state just compensation proceedings are unavailable or inadequate. $I d$. at 197 . If the federal court determines that such proceedings are fair and accessible, then the plaintiff is required to utilize them. 
The Court based this second requirement on the fact that "[t]he Fifth Amendment does not proscribe the taking of property; it proscribes taking without just compensation."25 As a result, the Court explained, "because the Fifth Amendment proscribes takings without just compensation, no constitutional violation occurs until just compensation has been denied."26 As a result of Williamson County, then, a property owner must pursue just compensation in state proceedings before he can enter federal court; if he attempts to bring a takings claim in federal court without pursuing just compensation, his claim will be dismissed.

The logic of Williamson County would suggest that a property owner does not have a ripe takings claim when she enters state proceedings to obtain just compensation. ${ }^{27}$ State courts, however, have generally treated just compensation proceedings as an inverse condemnation trial on a takings claim (despite the fact that the claim does not yet exist). ${ }^{28}$ This latter approach minimizes confusion over pleadings for plaintiffs, who can simply allege a violation of the takings clause, but the state courts' willingness to adjudicate both takings and substantive due process claims creates a potential for preclusion problems. ${ }^{29}$

\section{The SPLit IN THE FedERAL COURTS OVER THE RIPENESS REQUiREMENTS For Substantive Due Process Claims}

Because Williamson County involved a takings claim but not a substantive due process claim, lower courts faced with both a takings claim and a substantive due process claim based on property have had to determine the applicability of the Williamson County just compensation requirement to substantive due process claims without explicit guidance from the Supreme Court. In particular, the Courts of Appeals for the First and Ninth Circuits have addressed this issue and reached different results. ${ }^{30}$

25. Id. at 194.

26. Id. at $194 \mathrm{n} .13$ (emphasis in original).

27. This flows from the fact that a federal takings claim is ripe only after denial of just compensation.

28. The just compensation proceeding in Tennessee to which the Court in Williamson County sent the plaintiff was an inverse condemnation trial on the takings claim. See 473 U.S. at 196; see also Bateson v. Geisse, 857 F.2d 1300, 1306 (9th Cir. 1989) (Montana provides trial on inverse condemnation claim as its just compensation proceeding); Carroll v. City of Prattville, 653 F. Supp. 933, 942 (M.D. Ala. 1987) (Alabama's just compensation proceeding is inverse condemnation trial). For a useful discussion of many of the cases in which federal courts have sent takings and substantive due process claims to state proceedings, see Blaesser, Closing the Federal Courthouse Door on Property Owners: The Ripeness and Abstemtion Doctrines in Section 1983 Land Use Cases, 2 HoFSTRA PROP. L.J. 73 (1988).

29. See infra text accompanying notes 43-58. A plaintiff could try to avoid state court adjudication of her federal claims by grounding her suit in similar state law (if it exists). The Williamson County opinion. however, did not indicate that state refusal to compensate for state takings claims would be sufficient to ripen a Fifth Amendment takings claim. Thus plaintiffs who bring only state claims in state court and then enter federal court may find that they still have not satisfied the requirements of Williamson County.

30. The Eleventh Circuit has also considered this issue, with varying results (though it has never explicitly ruled on it). In Corn v. City of Lauderdale Lakes, 816 F.2d 1514 (11th Cir. 1987), the court 
The Ninth Circuit's approach to the just compensation issue can be seen in two cases, Sinaloa Lake Owners Association v. City of Simi Valley ${ }^{31}$ and Bateson v. Geisse..$^{32}$ In each case, property owners alleged that a particular governmental act constituted both a taking and a deprivation of substantive due process. ${ }^{33}$ In both cases the plaintiffs had not pursued just compensation at the state level for either their takings or their substantive due process claim. Both courts ruled that, because the plaintiffs had not sought just compensation, the takings claims were unripe under the just compensation requirement of Williamson County. The courts also ruled, though, that the substantive due process clai: 15 were ripe because substantive due process claims are not subject to the just compensation requirement. ${ }^{34}$ In both cases, then, the courts adjudicated the substantive due process claim and dismissed the takings claim.

Culebras Enterprises Corp. v. Rivera Rios ${ }^{35}$ and Ochoa Realty Corp. v. Fari $a^{36}$ also involved plaintiffs who claimed that certain acts by the government had both violated their substantive due process rights and amounted to a taking without just compensation. ${ }^{37}$ In these cases, the First Circuit held that both claims were not ripe because the plaintiffs had not sought just compensation in state proceedings. The Culebras holding (which the court quoted and followed in Ochoa) stated that "there can be no violation of substantive due

suggested that plaintiffs must pursue just compensation at the state level for both takings and substantive due process claims because, in Williamson County, "the Supreme Court implicitly ruled that the same ripeness test must be applied to both claims." Id. at 1516 n.2. In Greenbriar, Ltd. v. City of Alabaster, 881 F.2d 1570 (11th Cir. 1989), however, the court characterized the statement in Corn as dictum and stated that "[a] property owner has been denied substantive due process ... the moment a governmental decision affecting his property has been made in an arbitrary and capricious manner, regardless of whether he is later compensated for that violation." Id. at 1574 n.8. On that basis, the court found that the plaintiff need not have pursued just compensation in order to have a ripe substantive due process claim. Finally, the Eleventh Circuit largely reaffirmed the Greenbriar rule on just compensation in Eide v. Sarasota County, 908 F.2d 716 (1lth Cir. 1990), cert. denied, 111 S. Ct. 1073 (1991), except that the court in Eide, after dichotomizing substantive due process claims into "arbitrary and capricious due process claims" and "due process takings claims," suggested that Greenbriar only applied to the former and that, with respect to the latter, it was not clear whether pursuit of just compensation was required. Id. at 721-22, 725 n.16.

As was noted above, however, none of these cases actually ruled on the applicability of the just compensation requirement to substantive due process claims. In light of this fact, this Note will focus on the merits and demerits of the First and Ninth Circuits' rules. It should be noted, though, that insofar as Greenbriar reflects the Eleventh Circuit's position on this issue, the analysis of the Ninth Circuit's approach also applies to the Eleventh Circuit.

31. 882 F.2d 1398 (9th Cir. 1989), cert. denied sub nom. Doody v. Sinaloa Lake Owner's Ass'n, 110 S. Ct. 1317 (1990).

32. 857 F.2d 1300 (9th Cir. 1988).

33. In Simi Valley, the property owners challenged a state agency's rupture of a dam. 882 F.2d at 1401, 1404. In Bateson, the allegedly unconstitutional act was a city council's denial of a building permit and its attempt to rezone the plaintiff's property. 857 F.2d at 1302 .

34. See Simi Valley, 882 F.2d at 1404; Bateson, 857 F.2d at 1303 (plaintiff "was not required to seek 'just compensation' from state entities before bringing this substantive due process claim, and therefore this claim is ripe for adjudication"); see also Arroyo Vista Partners v. County of Santa Barbara, 732 F. Supp. 1046, 1050 (C.D. Cal. 1990) (substantive due process claim ripe because "the second prong of the Williamson test does not apply").

35. 813 F.2d 506 (1st Cir. 1987).

36. 815 F.2d 812 (1st Cir. 1987).

37. See Culebras, 813 F.2d at 507-08; Ochoa, 815 F.2d at 814 . 
process ... at least until the state inverse condemnation proceeding is resolved." ${ }^{38}$ Thus, the First Circuit requires that, in order for a plaintiff to have a ripe substantive due process claim, she must first pursue just compensation at the state level..$^{39}$

\section{Drawbacks of Sending Substantive Due Process Claims to STATE PROCEEDINGS}

\section{A. Problems with the First Circuit Rule}

The most obvious problem with requiring that a litigant pursue just compensation in order to have a ripe substantive due process claim is that there seems to be no basis for such a rule in the language of the Fourteenth Amendment. The takings clause of the Fifth Amendment specifically refers to just compensation; the due process clause of the Fourteenth Amendment does not include any language about compensation. The first portion of each clause outlines a governmental power, namely, the power to deprive of life, liberty, or property and the power to take land; and the second portion of each clause places a limitation on that power, namely, that life, liberty or property can be deprived only if there is due process of law, and that land can be taken only if just compensation is given. There is no requirement that due process be violated for a taking to occur, nor that just compensation be denied for a deprivation of life, liberty, or property to occur. Just compensation is thus relevant to a taking but irrelevant to a deprivation of substantive due process.

This conclusion comports with the Supreme Court's reasoning in Williamson County. According to the court, the just compensation requirement is based on "the special nature of the Just Compensation Clause," ${ }^{40}$ i.e., the fact that the clause specifically mentions just compensation. The Court did not intimate that any other clause or amendment might also be subject to the just compensation requirement; in fact, the opinion distinguished due process claims from takings claims on the basis of the reference to just compensation. ${ }^{41}$ The Court's explicit reliance on the language of the takings clause indicates that, since no other clatse mentions just compensation, pursuit of just compensation is not necessary for a cause of action to accrue under any other constitutional provision.

38. 813 F.2d at 516; see also Ochoa, 815 F.2d at 817 n.4.

39. See also Martinez v. Junta de Planificacion de Puerto Rico, 736 F. Supp. 413, 418 (D.P.R. 1990) (just compensation applies to substantive due process claims): Golemis v. Kirby, 632 F. Supp. 159, 163 (D.R.I. 1985) (takings claim as well as substantive due process claim are unripe for failure to pursue just compensation in state courts because "the Court [in Williamson County] has plainly signalled that the same considerations of ripeness [apply]").

40. 473 U.S. at 195 n.14.

41. Id. 
This reasoning follows from the principle that substantive due process is concerned with the state's aims and its methods of achieving them. ${ }^{42}$ If the state's aims or methods are arbitrary and unfair, then it has deprived someone of her right to life, liberty, or property under the due process clause. The state may be forced to compensate its citizens for that lack of fairness, but such compensation is a remedy for a deprivation without due process, not a preclusion of the deprivation (as it would be in the case of a takings claim). The deprivation lies in the state's original unfair action.

In addition to this constitutional objection, there is also a danger of preclusion under the First Circuit's approach: state rulings on substantive due process might have a preclusive effect, thereby denying plaintiffs a federal forum for their federal claim. Under 28 U.S.C. $\$ 1738$, the federal courts are bound by a state determination and cannot hear a given claim if the state accords a preclusive effect to its adjudication of that claim. ${ }^{43}$ That statute provides that the judicial proceedings of each state "shall have the same full faith and credit in every court within the United States . . . as they have by law or usage in the courts of such State ... from which they are taken." ${ }^{\text {44 }}$ Because the Supreme Court has ruled that section 1983 is not an exception to 28 U.S.C. $\$ 1738,{ }^{45}$ state adjudication of a section 1983 claim has the same preclusive effect in federal court as it would in a state court. Furthermore, the Supreme Court has held that, regarding section 1983 claims, federal courts "must give [administrative] factfinding the same preclusive effect to which it would be entitled in the State's courts." ${ }^{26}$ Thus, if a state court adjudicates a given claim and assigns a preclusive effect to its determination, the federal courts are bound by that decision and cannot hear the claim, even if the proceeding was merely an administrative hearing.

Consequently, a plaintiff whose substantive due process claim ${ }^{47}$ is sent to state proceedings will be subject to state preclusion rules unless she can preserve it by making a reservation as outlined in England v. Louisiana State Board of Medical Examiners..$^{48}$ In England, the Court ruled that, when a federal court sends a litigant to state court for adjudication of her state claims, the litigant can reserve her federal claims if she so informs the state court. ${ }^{49}$ The England holding, though, applied to plaintiffs with ripe federal claims who were sent to state court; it may not apply to plaintiffs who are sent to state

42. See supra text accompanying notes 16-18.

43. For a delineation of the elements of preclusion (and of the bases for a court's assigning preclusive effect to its adjudication), see W. FREEDMAN, RES JUDICATA AND COLLATERAL ESTOPPEL 11-30 (1988).

44. 28 U.S.C. $\$ 1738$ (1988).

45. See Migra v. Warren City School Dist. Bd. of Educ., 465 U.S. 75 (1984); Allen v. McCurry, 449 U.S. 90 (1980).

46. University of Tenn. v. Elliott, 478 U.S. 788,799 (1986).

47. It is important to note that the danger of preclusion also applies to takings claims. For more on this issue, see Blaesser, supra note 28.

48. 375 U.S. 411 (1964).

49. Id. at 421 . 
court because their claims are unripe. The Supreme Court has never ruled whether plaintiffs with unripe claims can avoid preclusion with an England reservation. The Court in England, however, based its holding on its "fundamental objections to any conclusion that a litigant who has properly invoked the jurisdiction of a Federal District Court ... can be compelled ... to accept instead a state court's determination of those claims," that, where a plaintiff does not properly invoke a federal court's jurisdiction because her claim is unripe, England may not protect her claim. ${ }^{51}$ Thus, if a state accords a preclusive effect to its just compensation proceedings, and if an England reservation is not available, then a plaintiff whose substantive due process claim was sent to state court will be barred, even though she was sent to the state proceeding by a federal court. In other words, by the time a plaintiff's claim is perfected, it may also be precluded. $^{52}$

There has been only one federal case in which a property owner has attempted to perfect takings and substantive due process claims in state court before entering federal court. In that case, Peduto v. City of North Wildwood, ${ }^{53}$ the federal court ruled that the plaintiff was precluded by the state court determination. In Peduto, the plaintiffs brought takings, substantive due process, and procedural due process claims to state court solely to satisfy the requirement of pursuing just compensation, as propounded in Williamson County. The plaintiffs had not attempted to make an England reservation, but the court indicated that such a reservation might not have been available to them anyway. The court stated that "[a]lthough a plaintiff in state court for the sole purpose

50. Id. at 415 (emphasis added).

51. This proposition presupposes that ripeness is not solely prudential but also has a jurisdictional element. Though there is no consensus among jurists and commentators on this issue, many courts have stated that ripeness is an aspect of jurisdiction. See, e.g., Tenoco Oil Co. v. Department of Consumer Affairs, 876 F.2d 1013, 1029 n.23 (1st Cir. 1989) ("A determination that a claim is not ripe deprives a court of jurisdiction."); Sinaloa Lake Owner's Ass'n v. City of Simi Valley, 882 F.2d 1398 (9th Cir. 1989), cert denied sub nom. Doody v. Sinaloa Lake Owner's Ass'n, 110 S. Ct. 1317 (1990) ("[R]ipeness is a jurisdictional requirement and lack of subject matter jurisdiction may not be waived."); In re Grand Jury, April 1979, 604 F.2d 69, 72 (10th Cir. 1979) ("The question of ripeness affects our subject matter jurisdiction."). See generally 13A C. WRIGHT, A. MILLER \& E. COOPER, FEDERAL PRACTICE AND PROCEDURE § 3532.1 (1984 \& Supp. 1991) [hereinafter WRIGHT \& MILLER].

52. Under the logic of Williamson County, this danger of preclusion should not occur: plaintiffs cannot be precluded from bringing claims in federal court that they did not have in state court, and the takings and substantive due process claims could not have been brought in state court since they did not yet exist (just compensation for those claims having not yet been denied). The problem is that state courts have generally treated the state proceedings as trials on the relevant constitutional claims that should be accorded preclusive effect. See supra note 28 and accompanying text.

A state could try to create an adjudicatory system that recognized that plaintiffs do not yet have ripe takings and substantive due process claims, and that therefore might not preclude those claims; no state has done $s 0$, however. Furthermore, assuming that a state did create such a system and looked only to state law for a guarantee of substantive due process or its equivalent, current Supreme Court doctrine might still provide for preclusion. See Kremer v. Chemical Constr. Corp., 456 U.S. 461 (1982) (state court decision regarding state claim precludes federal court adjudication of federal claim, where federal and state claims require same elements).

Of course, even if a nonpreclusive system were created, there would still be no constitutional justification for sending a federal substantive due process claim to state just compensation proceedings.

53. 696 F. Supp. 1004 (D.N.J. 1988), aff d, 878 F.2d 725 (3d Cir. 1989). 
of ripening its federal constitutional claim should be able to escape that state's claim preclusion rules under the logic of England, present Supreme Court caselaw makes such a result difficult to reach." $" 54$ The court thus acknowledged that a plaintiff might be precluded even if she did everything possible to avoid preclusion.

Because the First Circuit's approach potentially deprives plaintiffs of the ability to enter federal court, it prevents the effectuation of concurrent jurisdiction. The Supreme Court has interpreted section 1983 to provide for concurrent jurisdiction in the federal and state courts over constitutional claims. ${ }^{55}$ Thus a plaintiff with a ripe section 1983 claim should be able to choose whether to bring her claim in state or federal court. If, however, a state's preclusion rules prevent a plaintiff from entering federal court after a state proceeding, then the plaintiff has been denied her choice of forum. The only possibility of federal court adjudication would be review by the U.S. Supreme Court, which would be highly improbable given the overwhelming number of litigants who petition for certiorari. ${ }^{56}$ In the likely event that the Supreme Court did not review the case, then vindication of certain federal rights (namely, the plaintiff's right to substantive due process) would be left to the states.

This is not an issue of the suitability of state courts as fora for federal claims. Irrespective of the state courts' adequacy to hear substantive due process claims, sending such claims to state courts prevents plaintiffs from exercising the choice that is the basis of concurrent jurisdiction. Section 1983 was written specifically to avoid such a result by ensuring that a federal forum would be accessible. ${ }^{57}$ Thus, insofar as a requirement that a plaintiff utilize state proceedings prevents the plaintiff from entering federal court with federal claims, the requirement frustrates the purpose of section 1983 by denying concurrent jurisdiction. ${ }^{58}$

One final problem with the First Circuit's rule is that the opinions in Culebras and Ochoa do not articulate any criteria that would allow only property-based substantive due process claims to be sent to state court. Their

54. Id. at 1011 .

55. Allen v. McCurry, 449 U.S. 90, 99 (1980); Monroe v. Pape, 365 U.S. 167, 183 (1961).

56. Moreover, the Supreme Court would engage in appellate review rather than a trial on the merits.

57. See Monroe, 365 U.S. at 183 ("The federal remedy [under section 1983] is supplementary to the state remedy, and the latter need not be first sought and refused before the federal one is invoked.").

58. It may seem that this is analogous to the difficulties faced by habeas corpus petitioners, whose access to federal courts has been sharply curtailed in recent years. See, e.g., Allen v. McCurry, 449 U.S. 90 (1980) (prisoner who raised constitutional claims in state prosecution cannot bring them to federal court because collateral estoppel applies). Thus, it might be argued that denying a federal forum for a substantive due process claim is no different from denying a federal forum for a constitutional claim brought by a prisoner. There is an important distinction, however, that arises from the fact that prisoners were defendants in their original adjudications, but substantive due process claimants were plaintiffs. As noted above, plaintiffs, not defendants, choose between state and federal fora when there is concurrent jurisdiction. Since a defendant cannot choose his forum, it seems reasonable that his claims are fully adjudicated in the forum that the plaintiff chooses. But when a plaintiff's claims are sent to a forum that she did not choose, she has been denied the choice of forum that is inherent in concurrent jurisdiction. 
failure to distinguish among substantive due process claims suggests that all rights protected by that clause, including life and liberty, could be deprived as long as the state gives just compensation. Regardless of whether such a result seems desirable, it is too dramatic to be undertaken merely because of a desire to raise the ripeness requirements for takings-related substantive due process claims. If the federal courts are to deny access to plaintiffs with substantive due process claims, they should do so intentionally, rather than because they have failed to limit their theory to property-based claims.

\section{B. Requiring Pursuit of Just Compensation for Property Claims Only}

In light of the discussion above, one obvious modification of the First Circuit approach would be to limit its application to property-based claims, thereby mitigating the danger of sending life or liberty claims to state proceedings. The advantage of this alternative is that it would clear the federal courts of property-based substantive due process claims while ensuring that life and liberty due process claims remain in federal court. Under this rule, courts would make a determination as to whether there was a significant life or liberty interest involved and, on that basis, either send the case to state just compensation proceedings or hear it in federal court.

This approach seems attractive because it minimizes the number of claims that would be sent to state courts, and it does so on a rational basis: property is by its nature a commodity that has a market value, such that compensation can be determined in a relatively objective manner (i.e., by looking at the market), whereas life and liberty seem to defy any sort of market valuation. This distinction, however, is not supported by the due process clause, which does not differentiate among life, liberty, and property. The drafters of the Fifth and Fourteenth Amendments could very easily have included language that would have distinguished property from life or liberty; their failure to do so suggests that no such distinction was intended. ${ }^{59}$ In light of this failure to differentiate between property and life or liberty, it seems both unfair and unprincipled to send property claims to state courts while allowing life and liberty claims to be heard in federal courts.

One constitutional interpretation that would provide a distinction between property claims and life or liberty claims is that the former are already protected by the takings clause, so that no greater protection is needed. This interpretation collapses the distinction between the takings clause of the Fifth Amendment and the property component of the due process clause of the Fourteenth

59. Supreme Court doctrine also fails to support a distinction between life and liberty interests, on the one hand, and property interests, on the other. See Lynch v. Household Fin. Corp., 405 U.S. 538, 552 (1972) ("[T]he dichotomy between personal liberties and property rights is a false one. . . In fact, a fundamental interdependence exists between the personal right to liberty and the personal right in property. Neither could have meaning without the other."). 
Amendment by saying that, in property cases, just compensation satisfies the demands of due process. If this were the case, however, the inclusion of property in the due process clause would be meaningless; it would simply be excess verbiage, since all of the protection for property rights would have been outlined previously in the takings clause. As a matter of constitutional interpretation, the idea that the reference to property in the due process clause adds nothing is of dubious merit. ${ }^{60}$ The writers of the Fourteenth Amendment must have included property in the due process clause because they were outlining rights that had not yet been delineated. ${ }^{61}$

Thus, regardless of whether the class of claims sent to state proceedings is limited to those based on property, constitutional infirmities exist. If a federal court sends all substantive due process claims to state proceedings, it does so despite the lack of any constitutional connection between due process and just compensation. If a federal court decides instead to limit the class of unripe claims to property-based substantive due process claims, the original infirmity is still present (because there are still some claims sent to state just compensation proceedings), and there is an additional problem-namely, the fact that the Constitution does not support a distinction between property claims and life or liberty claims. In short, any approach that sends due process claims to state proceedings does so despite the lack of a constitutional basis and thus fails to offer a reasonable option for federal courts.

\section{Shortcomings of FaIling To Send Substantive Due Process Claims to State PRoceEdings}

\section{A. Problems with the Ninth Circuit Approach}

The main problem with a federal court's hearing a substantive due process claim while sending a takings claim to state proceedings is that it constitutes

60. See Marbury v. Madison, 5 U.S. (1 Cranch) 137, 174 (1803) ("It cannot be presumed that any clause in the constitution is intended to be without effect.").

61. It might be argued that the writers of the Fourteenth Amendment included property in that Amendment to guarantee procedural due process rights but not substantive due process rights. That is, they might have assumed that the takings clause already guaranteed substantive due process rights, and they merely added to the takings clause the guarantees of procedural fairness. The appeal of this theory is that it makes relevant the reference to property in the due process clause and still allows courts to distinguish property-based from life- or liberty-based substantive due process claims. There is no basis for this theory in the text of the Constitution, however. Nowhere in the Fourteenth Amendment is there a reference to the dichotomy between procedural and substantive due process, nor is there anything to indicate that the takings clause was intended to provide all the substantive safeguards necessary.

There is another problem with the argument based on a procedural/substantive due process distinction: Does the Constitution's silence about substantive due process rights to life and liberty indicate that those rights, also, were considered to be delineated elsewhere in the Constitution, and that only procedural due process was contemplated? That is, if the substantive component of property rights is to be found outside the due process clause, why doesn't that reading apply to the substantive component of life and liberty rights? If it is reasonable to say that the Fifth Amendment supplied the substantive component for property, then it seems equally reasonable to say that the first eight amendments supplied it for life and liberty. 
an inefficient use of federal courts' resources. Whether or not the state compensates for the alleged taking, the federal court wastes valuable time and energy by hearing the substantive due process claim immediately.

If the state grants just compensation for the takings claim, the federal court will have adjudicated a claim that it might have been able to avoid. As a doctrinal matier, a plaintiff who receives just compensation for his takings claim still has a valid substantive due process claim, because the latter claim is for damages, not just compensation. As a practical matter, however, plaintiffs who are compensated for a taking sometimes decide not to pursue their substantive due process claim, ${ }^{62}$ presumably because they are uncertain whether the amount of damages will be any greater than the amount of just compensation. ${ }^{63}$ Since a plaintiff might choose not to pursue her substantive due process claim in federal court if she receives just compensation for her takings claim at the state level, a federal court that waits for the state adjudication of the takings claim might not have to adjudicate the substantive due process claim and thereby will save judicial resources. Under the Ninth Circuit approach, however, the federal courts do not wait for the state courts and thus fail to take advantage of the opportunity to avoid adjudication of the substantive due process claim.

If the state court decides not to compensate, and if the litigant has sufficient resources to return to federal court, the federal court hears the substantive due process and takings claims separately ${ }^{64}$ The federal court, in adjudicating the takings claim, will review the same facts it has considered in the substantive due process context ${ }^{65}$ and then come to conclusions of law. As a result, the federal court will consider, at two different times, two similar claims based on the same set of facts. Clearly, the court's time would be utilized more efficiently if it considered the entire controversy at once. ${ }^{66}$

62. For example, when Hamilton Bank appealed the Tennessee district court's decision to the Sixth Circuit, it requested that the court award it compensation for a taking or, in the alternative, that the court grant a new trial on its substantive due process claim. (The district court had granted Williamson County a directed verdict on that claim.) Hamilton Bank v. Williamson County Regional Planning Comm'n, 729 F.2d 402, 404 (6th Cir. 1984). In other words, Hamilton Bank requested that the court rule on the substantive due process claim only if the court did not award takings compensation.

63. See supra text accompanying notes 19-21.

64. The court could avoid considering the takings question if it assigned some preclusive effect to its earlier ruling on the substantive due process claim or to the state court's ruling on just compensation for the takings claim, but such an approach would deny the litigant an opportunity to have her takings claim heard in federal court. On the problems associated with such preclusion, see supra text accompanying notes 43-58.

65. Unless circumstances were to change between the two adjudications, the only new fact would be the state court's refusal to compensate.

66. In addition to the inefficiency inherent in separate federal adjudications, it is also inefficient for federal and state courts to adjudicate claims based on similar facts. Whether or not the litigant returns to federal court, both the state and federal courts will have permitted discovery, heard motions, and found the facts. Neither court will have had the opportunity to accept the other's finding of facts because, under the Ninth Circuit approach, the federal court adjudicates the substantive due process claim at the same time that the plaintiff brings her claim to state court. 
Moreover, the two separate federal adjudications place a heavy burden on litigants. The litigants will have to engage in two separate litigation efforts despite the fact that the facts presented are identical, the potential damages are roughly equivalent, and the federal venue (if not the judge) is the same.

Another problem with the immediate adjudication of the substantive due process claim is that it fails to advance principles of federalism and comity. The Supreme Court has often emphasized the importance both of applying principles of federalism and of enhancing comity between the state and federal systems. ${ }^{67}$ The just compensation requirement of Williamson County seems to advance both federalism and comity by sending litigants to state courts for a ruling on the validity of actions undertaken by state or local actors. A rule that does not similarly require pursuit of just compensation at the state level for substantive due process claims, however, seems to frustrate the goals of federalism and comity, because the fairness and validity of the state or local agency's action will be directly before a federal court. ${ }^{68}$

\section{B. Federal Court Abstention/Certification with Respect to the Takings Claim}

Because immediate adjudication of substantive due process claims in federal court is inefficient and wastes resources, while sending the claims to state courts does not comport with the Constitution, we might be tempted to find an intermediate position. The obvious candidate is a rule providing that, when a plaintiff brings both takings and substantive due process claims in federal court, the federal court will send the takings claim to the state court for just compensation hearings and will refrain from hearing the rest of the case pending the state court's determination. ${ }^{69}$ Such a rule (which has not heretofore been implemented by a federal court) could be considered an abstention doctrine or certification of a question to a state court. ${ }^{70}$ Irrespective of the name, the process itself would involve a federal court's sending a takings claim to state just compensation proceedings while retaining jurisdiction over the substantive due process claim (and any other claims). Upon completion of the state proceeding, the federal court would adjudicate the remaining claims.

The main advantage of this proposal is that it avoids the inefficiency inherent in immediate federal court adjudication of the substantive due process claim but does not attempt to send the claim to state just compensation proceed-

67. See, e.g., Younger v. Harris, 401 U.S. 37 (1971) (Court's interest in federalism and comity required that state prosecution not be enjoined).

68. But see infra note 71 .

69. The federal court could retain jurisdiction over the substantive due process claim (and any others) or send the takings claim to state court without retaining jurisdiction over the substantive due process claim (i.e., by dismissing it pending state court action). The advantage of the federal court's retaining jurisdiction is that it enables the court to take steps to prevent unreasonable delay by the state courts. See P. BATOR,

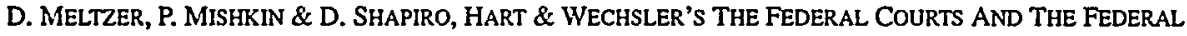
SYSTEM 1375 (3d ed. 1988) [hereinafter HART \& WECHSLER].

70. But see infra notes $72-73$ and accompanying text. 
ings. If the state did compensate and the plaintiff therefore decided not to pursue his substantive due process claim, the federal court would not have to adjudicate the substantive due process claim; this would save the court time and thereby reduce docket pressure. If the state did not compensate, or if the state court did compensate and the plaintiff chose to pursue his substantive due process claim anyway, the federal courts would hear the takings claim along with the substantive due process claim. Even under that scenario, the abstention/certification option would be more efficient than the Ninth Circuit approach, because it would allow the federal court to rule on similar claims in one adjudication. Under the Ninth Circuit rule, in contrast, the court would hear evidence and make determinations on similar claims in two separate adjudications. Thus, whether or not the plaintiff ultimately litigated his substantive due process claim in federal court, the proposed procedure would be more efficient than the Ninth Circuit rule. ${ }^{71}$

There are two significant drawbacks to the abstention/certification approach, however. First, it is not clear that certification would be available or that abstention would be appropriate. With respect to the former, only twenty-five states accept certified questions from federal district courts, and further limitations apply in some of those states. ${ }^{72}$ Abstention, in contrast, is universally accepted, but it may not be proper in this context. The practice in the federal courts has been to abstain when the unsettled issue involves the construction of a state statute. In the takings context, however, the issue is the application of (presumably settled) state law, and so abstention may not be appropriate. ${ }^{73}$

The second problem with this proposal is the potential for delay; after all, the Ninth Circuit approach has the advantage of adjudicating the substantive due process claim immediately, thereby effectuating the goal of prompt adjudication of federal claims. The abstention/certification approach, on the other hand, predicates further action in federal court upon the completion of the state

71. There is also a federaiism and comity issue involved in the choice between abstention and the Ninth Circuit approach, but it is not clear which approach does more to advance (or, perhaps, less to frustrate) federalism and comity. On the one hand, the abstention/certification procedure, by opening up the possibility that the federal court might not have to adjudicate the substantive due process claim, seems to advance federalism and comity because the federal court might not have to sit in judgment of the state's action. On the other hand, the abstention/certification regime, by providing for federal court adjudication of the substantive due process claim after the state proceeding has concluded, seems to place the federal court in the position of second-guessing the state court. (Of course, this appearance of judging the legitimacy of state proceedings occurs whenever a federal court reviews a state court's actions; and since such review is contemplated by Williamson County, it might be argued that the real frustration of federalism and comity results from the just compensation requirement itself.)

72. See 17A WRIGHT \& MILLER, supra note 51, \$ 4248 .

73. There is one existing form of abstention that may be analogous to abstention in the takings context: Burford abstention, named after Burford v. Sun Oil, 319 U.S. 315 (1943). The abstention in that case was based in large part on the sensitive and complex nature of the regulation of oil and gas; the state was attempting to formulate a policy, and the federal courts decided not to interfere. Such reasoning probably will not apply in all takings cases, however. While, in some situations, takings may occur in the context of a complex state plan to regulate a certain form of property, in many takings cases there is no issue of a complex regulatory scheme. For a more complete explication of abstention and certification, see HART \& WECHSLER, supra note 69, at 1346-1454: 17A WRIGHT \& MILLER, supra note 51, \$\$ 4241-4248. 
just compensation proceedings. This avoids separate litigation at the federal level, but it also could entail delays of many months or even years while the federal court waits for the state to decide whether to compensate. Abstention/certification therefore mitigates the inefficient use of the federal courts' resources, but only at the expense of the plaintiff's interest in a speedy disposition of her claims.

Thus, leaving to one side the problem of fashioning a new form of abstention, the abstention/certification approach does not solve the problem of inefficiency and waste of resources. Rather, it replaces one form of inefficiency and waste (hearing a substantive due process claim that might have been avoided or consolidated with the takings claim) with another (allowing litigation to drag on for years). This second form of waste is chiefly visited upon the litigants rather than the courts, but it constitutes a cost nonetheless. ${ }^{74}$ We might prefer that, if there is to be an expense, it be borne by the litigants rather than the courts, but that still begs the question of why anyone should be forced to bear such a burden in the first place, especially since (as both the Ninth Circuit and the abstention/certification approaches presume) the plaintiff with the substantive due process claim is properly before the federal court.

\section{Partial Overruling of Williamson County}

This Note has examined two general methods for adjudicating takings and substantive due process claims that are based on the same facts. The first (the Ninth Circuit approach and the abstention/certification proposal) sends one claim to state court and provides for hearing the other in federal court. The second (the First Circuit approach and the proposed modification limiting it to property-based claims) sends both claims to state court. There is a third possibility, however: adjudication of both takings and substantive due process claims in federal court.

Implementation of this approach, of course, would require abandoning Williamson County's mandate that plaintiffs pursue just compensation at the state level. This requirement could be replaced with a system that allows federal courts to determine whether state law provides for compensation in a given situation. State refusal to compensate would still be a prerequisite for a ripe takings claim, but the federal court would determine whether state law mandates just compensation. ${ }^{75}$ The only change would be that the federal court, rather

74. The cost of delay, in fact, would impose such an enormous burden on litigants that it would probably outweigh any increases in efficiency resulting from the abstention/certification regime. The cost to litigants, combined with the fact that certification might not be available and abstention might not be proper, indicates that the Ninth Circuit approach might be preferable.

75. For an alternative modification of Williamson County, under which the Supreme Court would eliminate state refusal to compensate as a prerequisite for a ripe takings claim, see infra note 77. 
than the state court, would apply state just compensation law. ${ }^{76}$ If the federal court determined that, under state law, just compensation were required, it would order the state to compensate for the taking (just as a state court would) and then could address any other claims that the plaintiff wanted to pursue. If the federal court determined that state law did not provide compensation, then the takings claim would be ripe for adjudication on the merits with the rest of the claims. Thus, under this approach, the federal court would either require that the state or local agency award just compensation or find that the plaintiff was not entitled to compensation. ${ }^{77}$

The advantage of this proposal is that it recognizes that just compensation is relevant to a takings claim but irrelevant to a substantive due process claim, and, at the same time, provides for timely adjudication of both claims in a manner that maximizes the efficient use of the federal courts' resources. ${ }^{78}$

The one drawback of this approach is that it places federal courts in the role of determining whether state law mandates just compensation, and, therefore, might sometimes fail to advance the goals of federalism and comity between state and federal courts. These goals, however, will be similarly frustrated to the extent that substantive due process claims are heard in federal court; and, as this Note has indicated, there is no coherent constitutional basis for sending those claims to state just compensation proceedings. Thus, the goals of federalism and comity will not be advanced as long as federal courts recognize their obligation to hear substantive due process claims. Furthermore, it should be remembered that federal courts are competent adjudicators of state-law claims. Most important, as the Supreme Court has noted, "it was never a doctrine of equity that a federal court should exercise its judicial discretion to dismiss a suit merely because a State court could entertain it.",79

76. Of course, if the state did not even allow its courts to grant just compensation, then, whether or not Williamson County were overruled, the federal court would hear the takings claim without inquiring further into the issue of just compensation.

77. A different form of abandonment of the just compensation rule is also possible: the Supreme Court could simply reject the denial of just compensation as a prerequisite for a takings claim. Under such an approach, a plaintiff would not be required to pursue just compensation in any forum. The problem with such an approach, however, is that, although just compensation is irrelevant to a substantive due process claim, it is relevant to a takings claim, and thus it makes sense to have a just compensation ripeness threshold for takings claims. In short, just as requiring pursuit of just compensation is inappropriate for substantive due process claims, failing to do so seems illogical for takings claims. Thus the better solution is to preserve the just compensation requirement but allow federal courts to decide whether just compensation should be given.

78. In addition, it avoids the preclusion difficulties outlined supra text accompanying notes 43-58, and is consistent with the purpose of section 1983-namely, that litigants be allowed to enforce federal rights in federal courts.

79. Colorado River Water Conservation Dist. v. United States, 424 U.S. 800, 813-14 (1976) (quoting Alabama Pub. Serv. Comm'n v. Southern Ry., 341 U.S. 341, 361 (1951) (Frankfurter, J., concurring)). 


\section{CONCLUSION}

This Note has demonstrated that each of the three basic regimes for adjudicating property-based substantive due process claims has significant drawbacks: sending substantive due process claims to state just compensation proceedings comports with neither the Constitution nor section 1983 and may give rise to preclusion; hearing substantive due process claims in federal court immediately (or after waiting for state action on a takings claim) while allowing takings claims to be sent to state proceedings wastes resources, fails to advance principles of federalism and comity, and, in the case of the abstention/certification route, may not be practicable under current certification statutes and abstention doctrines; and hearing both substantive due process and takings claims in federal court increases federal courts' caseloads and, by removing state courts from the process, frustrates the goals of federalism and comity.

The inquiry that remains, then, is an evaluation of these sets of shortcomings to determine which of the three approaches is preferable. Sending substantive due process claims to state courts seems to be the most objectionable, as it does not comport with the Constitution and frustrates its precepts: under the Fourteenth Amendment and section 1983 federal courts are open to plaintiffs who are aggrieved by states, and if courts fabricate constitutional doctrines to avoid such plaintiffs, they have violated the spirit of the Constitution. In contrast, while hearing federal claims in federal courts may not advance the goals of federalism, comity, and efficiency, it does not constitute a misreading of the Constitution; on the contrary, the Fourteenth Amendment and section 1983 clearly provide for a federal court hearing a claim that a state violated a person's constitutional rights. Thus, federal courts should not implement any approach (such as the First Circuit approach or its modification) that dismisses claims without a coherent constitutional basis.

The choice between the remaining two options, however, is not so clear, as neither involves a violation of the Constitution. We can differentiate between their drawbacks, though, because we can balance inefficiency and waste against enlarging federal dockets. The waste and inefficiency that result from bifurcating takings and substantive due process claims benefit no one and thus constitute a deadweight loss. Hearing both claims, in contrast, is neither inefficient nor wasteful. Increases (or decreases) in the federal caseload do not affect the efficiency of the courts' use of their resources; the increase in caseloads merely creates more work for the federal judiciary, which can be relieved by hiring more workers (i.e., judges). An increase in federal dockets thus does not waste scarce resources, because it is irrelevant to the utilization of those resources; rather, it simply leads to the conclusion that, if we want federal courts to fulfill their role in our constitutional system, we must make sure that they have adequate resources. Though many federal judges might dread the thought of more takings and substantive due process cases, such dread seems considerably 
less important than the problem of wasteful and inefficient use of courts' and litigants' time.

The best solution to the issues raised in this Note, therefore, is for federal courts to hear both takings and substantive due process claims, so that litigants are provided with a timely adjudication and the courts' (and litigants') resources are not wasted on two separate adjudications based on similar facts. This approach, however, does require a partial overruling of Williamson County. Unless and until the Supreme Court abandons the second requirement of Williamson County, the lower federal courts will have to work within the Williamson County framework. As this Note has demonstrated, that framework is inherently flawed: it requires courts either to separate two similar claims and thus waste valuable resources or to rule that just compensation is applicable to substantive due process and thus apply an incoherent constitutional theory. Given that choice, the courts should err on the side of constitutional coherence and utilize the Ninth Circuit's approach ${ }^{80}$ The most satisfactory answer, though, is an abandonment of the second requirement of Williamson County: federal courts should determine if state law provides just compensation and thereby avoid choosing between efficiency and constitutional coherence. In this case, then, the principles of federalism and comity must give way to the need to provide plaintiffs with a speedy and effective adjudication of their constitutional claims.

80. The Ninth Circuit approach is preferable to the abstention/certification option because of the problem of the practicability of the latter approach as well as the potential for enormous delay. See supra notes 72-74 and accompanying text. 